KEY WORDS: Performance Assessment

UDQ Evaluation LLW Disposal

\title{
Evaluation of Proposed Disposal of 331-M Standards in Trenches
}

\author{
Author \\ Leonard B. Collard \\ Westinghouse Savannah River Company \\ Savannah River Technology Center \\ Aiken, SC 29808
}

October 12, 2003

Westinghouse Savannah River Company

Savannah River Site

Aiken, SC 29808

Prepared for the U.S. Department of Energy Under

Contract Number DE-AC09-96SR18500

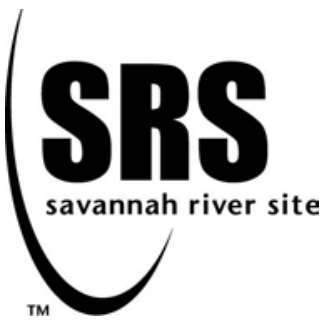


This document was prepared in conjunction with work accomplished under Contract No. DE-AC09-96SR18500 with the U. S. Department of Energy.

\section{DISCLAIMER}

This report was prepared as an account of work sponsored by an agency of the United States Government. Neither the United States Government nor any agency thereof, nor any of their employees, makes any warranty, express or implied, or assumes any legal liability or responsibility for the accuracy, completeness, or usefulness of any information, apparatus, product or process disclosed, or represents that its use would not infringe privately owned rights. Reference herein to any specific commercial product, process or service by trade name, trademark, manufacturer, or otherwise does not necessarily constitute or imply its endorsement, recommendation, or favoring by the United States Government or any agency thereof. The views and opinions of authors expressed herein do not necessarily state or reflect those of the United States Government or any agency thereof.

This report has been reproduced directly from the best available copy.

Available for sale to the public, in paper, from: U.S. Department of Commerce, National Technical Information Service, 5285 Port Royal Road, Springfield, VA 22161, phone: (800) 553-6847, fax: (703) 605-6900

email: orders@ntis.fedworld.gov

online ordering: http://www.ntis.gov/help/index.asp

Available electronically at http://www.osti.gov/bridge

Available for a processing fee to U.S. Department of Energy and its contractors, in paper, from: U.S. Department of Energy, Office of Scientific and Technical Information, P.O. Box 62, Oak Ridge, TN 37831-0062,

phone: (865)576-8401,

fax: (865)576-5728

email: $\underline{\text { reports@ adonis.osti.gov }}$ 


\section{$\underline{\text { Summary }}$}

Fifteen uranium standards and 1 bag of uranium scrap from 331-M were evaluated for disposal as low-level waste in slit trenches. This 331-M standards' waste differs from generic solid waste (e.g., contaminated tools and clothing) because it is in the form of uranium alloy slugs and scrap metal and contaminants will release more slowly from it. Therefore, the intruder limits for this waste will be less than the intruder limits for generic waste and they must be evaluated.

The evaluation in this report assigned the inventory limits for each pathway/scenario for generic waste to the 331-M standards' waste, except for the intruder scenarios. The air and radon limits for generic waste are directly applicable to the 331-M standards' waste. The inventory limits for the groundwater pathway for generic waste are lower than those that could be calculated for the 331-M standards waste if its slower leaching rate were considered.

Results indicate that the groundwater limits are always lower than the intruder limits, even when no leaching (i.e., only decay) is considered when determining the amount of contaminants present at the time of a hypothetical intrusion. Because the groundwater limits are lower they represent the PA operational limits for both generic waste and the 331-M standards' waste. The sums-of-fractions for each pathway/scenario are presented to parallel those shown in the timed sum-of-fractions report (Collard, 2003B). The maximum sum-of-fractions for any pathway/scenario for the 331-M standards' waste is identical to the PA sum-of-fractions for generic waste because the inventory limit for the groundwater pathway from 1000 to 10,000 years is always the lowest inventory limit for any pathway/scenario.

The operational limits do not change for this waste because the current groundwater pathway limits are more restrictive than the limits for any other pathway/scenario. Also the current groundwater limits are lower than those that would be calculated for the 331-M standards' waste because contaminants would leach more slowly than the contaminants would leach from generic waste.

When the mode of operation switches from the PA convention to the "Timed Sum-ofFractions" method, a Special Analysis will need to be in place that establishes the new intruder limits for the 331-M standards' waste. The Special Analysis for the slit trenches planned for FY2004 to help address issues in the Interim Measures report (Wilhite and Butcher, 2003) will incorporate the 331-M standards' waste. The planned Special Analysis may provide intruder limits that include leaching and a separate set of limits that exclude leaching. In that case the 331-M standards' waste would be covered by the limits that exclude leaching.

Alternatively, because the PA limit is bounding for the intruder scenarios, the PA limit may be substituted for the intruder scenario limits, instead of issuing a Special Analysis with the new limits for the intruder scenarios. However, for this alternative, the "Timed Sum-of-Fractions" report would need to be modified to allow such a substitution. 


\section{Introduction and Description of Proposed Activity}

Fifteen uranium standards in bags and 1 bag of uranium scrap from 331-M were evaluated for disposal as low-level waste in slit trenches based on a safety question (Reed, 2003). The inventory is provided in Table 1 (Gregory, 2003). This 331-M standards' waste differs from generic solid waste (e.g., contaminated tools and clothing) because it is in the form of uranium alloy slugs and scrap metal and contaminants will release more slowly from it.

Table 1. Inventory of 331-M Standards

\begin{tabular}{lccc}
\hline Nuclide & $\begin{array}{c}\text { Specific } \\
\text { Activity } \\
\text { (Ci/g) }\end{array}$ & $\begin{array}{c}\text { Weight } \\
\text { Bags 1-16 } \\
\text { (grams) }\end{array}$ & Activity \\
(Ci) \\
\hline $\mathrm{U}-232$ & $2.20 \mathrm{E}+01$ & $1.70 \mathrm{E}-03$ & $3.74 \mathrm{E}-02$ \\
$\mathrm{U}-233$ & $9.64 \mathrm{E}-03$ & $1.36 \mathrm{E}+00$ & $1.31 \mathrm{E}-02$ \\
$\mathrm{U}-234$ & $6.24 \mathrm{E}-03$ & $4.10 \mathrm{E}+00$ & $2.56 \mathrm{E}-02$ \\
$\mathrm{U}-235$ & $2.16 \mathrm{E}-06$ & $1.01 \mathrm{E}+03$ & $2.19 \mathrm{E}-03$ \\
$\mathrm{U}-236$ & $6.48 \mathrm{E}-05$ & $3.53 \mathrm{E}+00$ & $2.29 \mathrm{E}-04$ \\
$\mathrm{U}-238$ & $3.37 \mathrm{E}-07$ & $1.13 \mathrm{E}+05$ & $3.80 \mathrm{E}-02$ \\
Sum & & $1.14 \mathrm{E}+05$ & $1.17 \mathrm{E}-01$ \\
\hline
\end{tabular}

\section{$\underline{\text { Background }}$}

Contaminants on generic waste are assumed to be available for immediate transport via groundwater, but contamination from the 331-M standards' waste must first leach before they are available for transport. The method of analysis in this report only involved modifying the intruder analyses to represent the 331-M standards' waste. For the intruder analyses, the only change was to neglect leaching and only consider decay when calculating the amount of contaminant present at the time of the hypothetical intrusion. Contaminants from the 331-M standards' waste will release much more slowly than will contaminants from generic waste, thus the change in performance must be evaluated.

\section{Evaluation for proposed trench disposal}

Inventory limits for each pathway/scenario are provided in Table 2. All limits except for the intruder scenario limits were copied from the "Timed Sum-of-Fractions" report (Collard, 2003B) for generic waste. The existing radon analysis does not change for the 331-M standards' waste. The air pathway is not applicable for the 331-M standards' waste. Inventory limits for the groundwater pathway calculated for generic waste are smaller than the inventory limits that would be calculated for the 331-M standards' waste, if its slower leach rate were considered. The groundwater pathway is subdivided into three intervals to correspond to the "Timed Sum-of-Fractions" report (Collard, 2003B) tables. The intruder limits considered decay, but did not consider leaching. 
Table 2. Inventory (Ci) Limits for 331-M Standards with No Leaching for Intruder Scenarios

\begin{tabular}{|c|c|c|c|c|c|c|c|c|c|c|c|}
\hline \multirow[b]{2}{*}{ Nuclide } & \multirow[b]{2}{*}{$\begin{array}{l}\text { 331-M } \\
\text { Standards } \\
\text { Activity }\end{array}$} & \multicolumn{5}{|c|}{ Intruder and Other } & \multicolumn{3}{|c|}{ Groundwater } & \multirow{2}{*}{\begin{tabular}{|l}
\multicolumn{1}{c}{ PA } \\
$\begin{array}{l}\text { Minimum } \\
\text { Limit }\end{array}$
\end{tabular}} & \multirow{2}{*}{\begin{tabular}{l}
\multicolumn{1}{c}{ PA } \\
Maximum \\
Fraction \\
(unitless)
\end{tabular}} \\
\hline & & $\begin{array}{l}\text { Agricul- } \\
\text { tural }\end{array}$ & $\begin{array}{l}\text { Residen- } \\
\text { tial }\end{array}$ & $\begin{array}{c}\text { Post- } \\
\text { Drilling }\end{array}$ & Air & Radon & $\begin{array}{l}0-100 \\
\text { years }\end{array}$ & $\begin{array}{l}100- \\
1000 \\
\text { years }\end{array}$ & $\begin{array}{l}1000- \\
10000 \\
\text { Years }\end{array}$ & & \\
\hline U-232 & $3.74 \mathrm{E}-02$ & $1.7 \mathrm{E}+03$ & $3.2 \mathrm{E}+03$ & $1.2 \mathrm{E}+03$ & & & $5.9 \mathrm{E}+01$ & $5.9 \mathrm{E}+01$ & $5.9 \mathrm{E}+01$ & $5.9 \mathrm{E}+01$ & $6.34 \mathrm{E}-04$ \\
\hline U-233 & $1.31 \mathrm{E}-02$ & $1.2 \mathrm{E}+02$ & $1.5 \mathrm{E}+07$ & $3.4 \mathrm{E}+03$ & & & $1.9 \mathrm{E}+00$ & $1.9 \mathrm{E}+00$ & $1.9 \mathrm{E}+00$ & $1.9 \mathrm{E}+00$ & $6.90 \mathrm{E}-03$ \\
\hline U-234 & $2.56 \mathrm{E}-02$ & $3.6 \mathrm{E}+02$ & $1.9 \mathrm{E}+08$ & $3.6 \mathrm{E}+03$ & & $4.9 \mathrm{E}+01$ & $1.1 \mathrm{E}+02$ & $1.1 \mathrm{E}+02$ & $1.1 \mathrm{E}+01$ & $1.1 \mathrm{E}+01$ & $2.33 \mathrm{E}-03$ \\
\hline U-235 & 2.19E-03 & $2.6 \mathrm{E}+01$ & $6.6 \mathrm{E}+08$ & $3.2 \mathrm{E}+03$ & & & $5.7 \mathrm{E}+01$ & $5.7 \mathrm{E}+01$ & $8.0 \mathrm{E}+00$ & $8.0 \mathrm{E}+00$ & $2.73 \mathrm{E}-04$ \\
\hline U-236 & $2.29 \mathrm{E}-04$ & $4.6 \mathrm{E}+02$ & & $3.8 \mathrm{E}+03$ & & & $2.0 \mathrm{E}+00$ & $2.0 \mathrm{E}+00$ & $2.0 \mathrm{E}+00$ & $2.0 \mathrm{E}+00$ & $1.14 \mathrm{E}-04$ \\
\hline U-238 & $3.80 \mathrm{E}-02$ & $1.2 \mathrm{E}+02$ & $1.9 \mathrm{E}+06$ & $3.9 \mathrm{E}+03$ & & & $8.7 \mathrm{E}+00$ & $8.7 \mathrm{E}+00$ & $7.4 \mathrm{E}+00$ & $7.4 \mathrm{E}+00$ & $5.14 \mathrm{E}-03$ \\
\hline $\begin{array}{l}\text { U-234 } \\
(1000 \mathrm{yr} \\
\mathrm{Ag})\end{array}$ & $2.56 \mathrm{E}-02$ & $3.10 \mathrm{E}+02$ & & & & & & & & & \\
\hline Sum-of-1 & Fractions & & & & & & & & & & $1.54 \mathrm{E}-02$ \\
\hline
\end{tabular}

The smallest limit and the maximum fraction are shown in the right-most columns. The smallest limit is the current Performance Assessment (PA, McDowell-Boyer et al., 2000) operational limit. This table also shows an extra row entry for U-234 in the agricultural scenario at 1,000 years, as was done in the PA to show the peak for uranium decay products.

Inventory limits for generic waste are shown in Table 3 for comparison. For generic waste in the intruder scenarios, leaching was considered with decay, thus reducing the amount of contaminants present at the time of the hypothetical intrusion versus the no leaching case for the 331-M standards' waste. Only the agricultural and post-drilling intruder limits are higher for the generic waste. The residential values are the same for the generic waste and the 331-M standards' waste, because the PA did not consider leaching for this scenario. The U-235 limit for the residential scenario is different because of rounding.

Table 3. Inventory Limits (Ci) for Generic Waste with Leaching for Intruder Scenarios

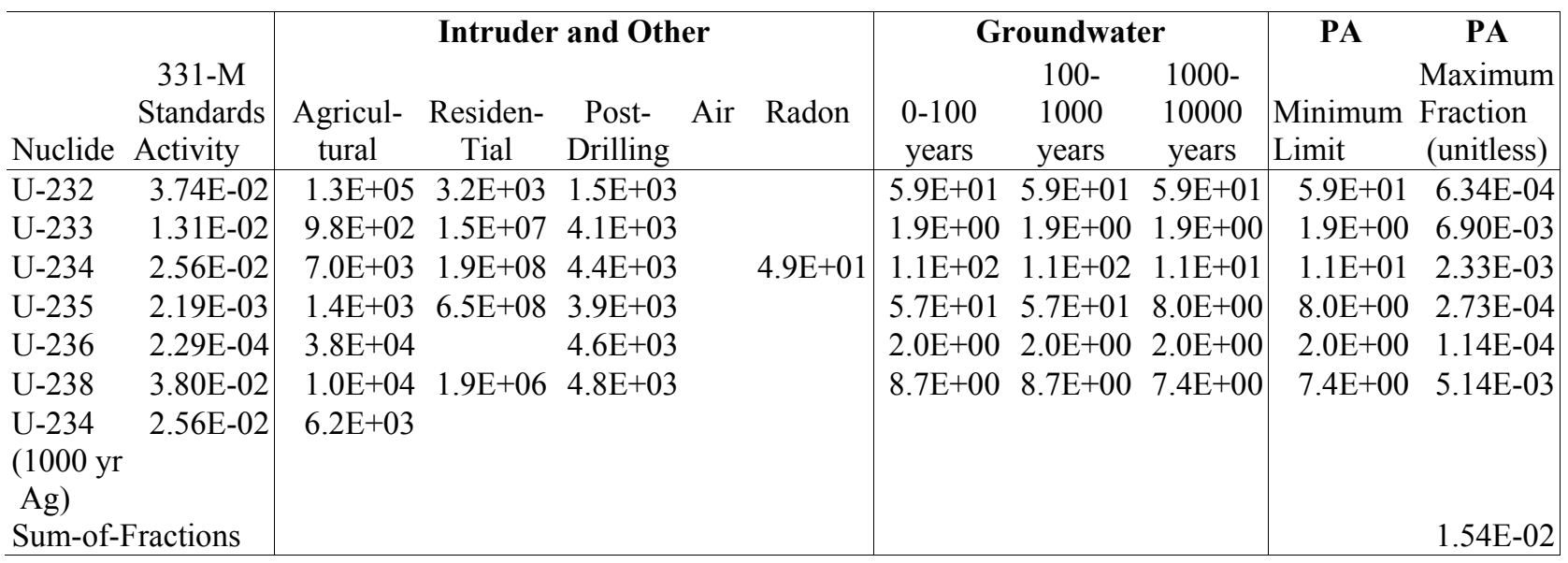


Table 4 shows the 331-M standards' inventory fractions calculated by dividing the inventory by the inventory limit (for the no leaching case shown in Table 2) for each scenario/pathway. The sum-of-fractions for each scenario/pathway is shown at the bottom of Table 4. A separate column shows the maximum sum-of-fractions for a scenario/pathway.

Table 4. Fractions of Inventory Limits for 331-M Standards

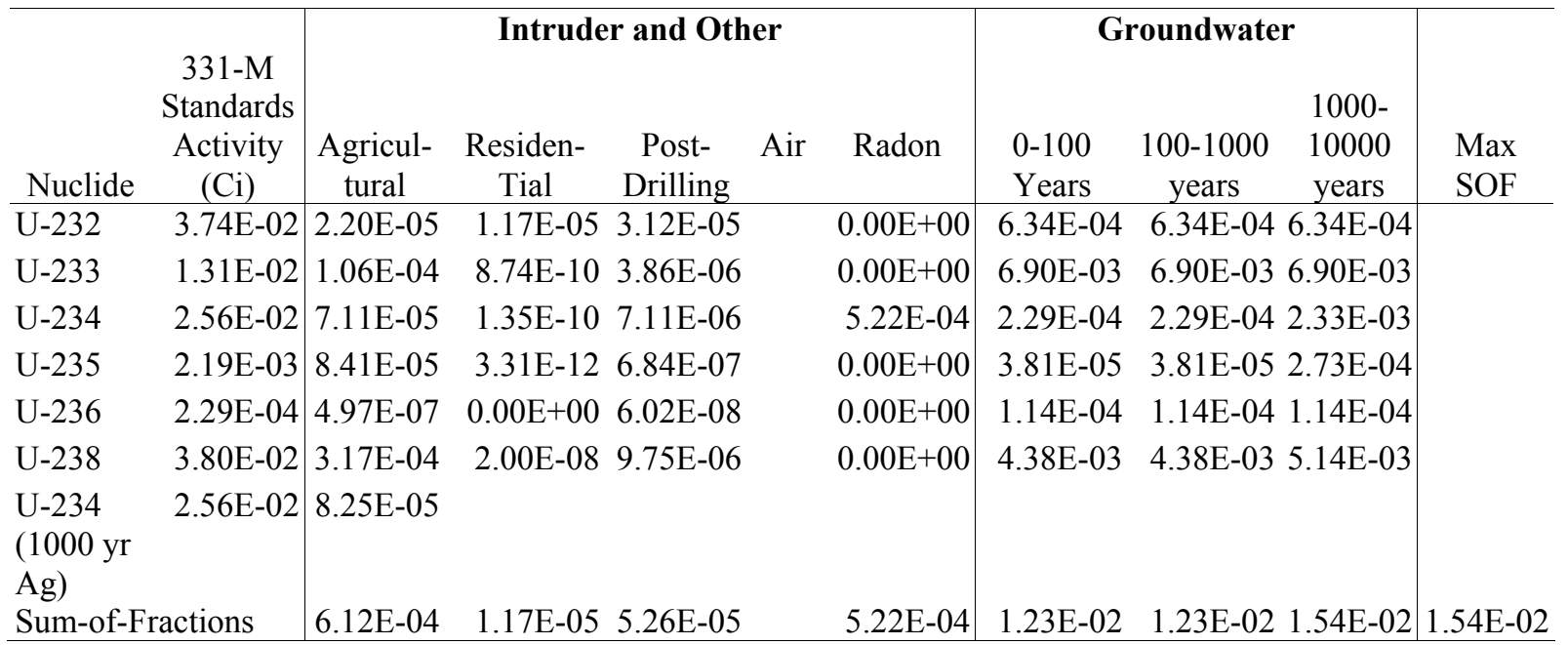

Note: the sum-of-fractions for the agricultural scenario includes the higher fraction for U-234 at 1000 years and excludes the standard fraction for U-234 at 700 years.

\section{$\underline{\text { Results }}$}

Three cases are presented above. The first case is for the PA limits for 331-M standards' waste with leaching excluded for the intruder scenarios. The second case (for comparison only) is for the PA limits for the inventory of the 331-M standards' waste analyzed as if leaching were considered. The third case is equivalent to the first case, except that the "Timed Sum-of-Fractions" are considered for future implementation.

The maximum sums-of-fractions are the same for all three cases, namely

1. 331-M standards' waste for the current PA method (Table 2)

2. generic waste for the current PA method (Table 3)

3. 331-M standards' waste for the "Timed Sum-of-Fractions" method.(Table 4)

The maximum sum-of-fractions did not change because the inventory limit for the third interval of the groundwater pathway always contained the lowest inventory limit. The current PA method differs from the "Timed Sum-of-Fractions," because the PA calculates each isotope's fraction by dividing that isotope's inventory by the lowest inventory limit from among all the pathways/scenarios for that isotope. However, if a single pathway/scenario always has the lowest inventory limits, then that 
pathway/scenario sets the PA limits. That single pathway/scenario will also always contain the highest fractions and thus the highest sum-of-fractions.

New limits were calculated for the individual intruder scenarios that are lower than the limits calculated in the PA for generic waste.

\section{Evaluation}

1. Does the proposed activity involve a change to the Performance Assessment or exceed PA performance measures/conclusions?

No. While individual inventory limits for intruder scenarios are lower than for generic waste, the most restrictive or operational limit is for the groundwater pathway and that limit does not change.

2. Does the proposed activity involve a:

a. change to the basic disposal concept as described in the PA?

No. Trench disposal of waste was analyzed in the PA.

b. change to the analyses or radionuclide limits as described in the PA?

No. The analyses and values of the operational limits did not change.

c. change in the disposal authorization that leads to a significant change in projected dose?

No. The proposed activity will not result in a significant change in projected dose.

d. change in the results in the approved PA that is greater than $10 \%$ ?

No. The proposed activity will not cause the results in the PA to change.

e. change of greater than $10 \%$ in the dose calculated in the approved PA?

No. The proposed activity will not increase the dose calculated in the PA.

f. Does the proposed activity modify the analysis or conclusions provided in the Composite Analysis (Cook, et al., 1999)?

No. The only change is for the intruder scenarios that are not included in the CA. While the inventory was not explicitly included in the CA, any disposal that is allowable under the PA is also allowable under the CA, because the limits and dilution are greater in the CA. 
g. change to the Disposal Authorization Statement (DOE, 1999)?

No. The proposed activity does not necessitate a change to the Disposal Authorization Statement.

\section{$\underline{\text { Conclusion }}$}

The operational inventory limits for the proposed activity, disposing 331-M standards' waste in slit trenches, did not change from the limits for generic waste. The inventory limits did decrease for most intruder scenarios, but the limits for the groundwater pathway were always lower, both for generic waste and for the 331-M standards' waste.

\section{$\underline{\text { Recommendations }}$}

The operational limits do not change for this waste because the current groundwater pathway limits are the more restrictive than the limits for any other pathway/scenario. Also the current groundwater limits are lower than those that would be calculated for the 331-M standards' waste because contaminants would leach more slowly than the contaminants would leach from generic waste.

When the mode of operation switches from the PA convention to the "Timed Sum-ofFractions" method, a Special Analysis will need to be in place that establishes the new intruder limits for the 331-M standards' waste. The Special Analysis for the slit trenches planned for FY2004 to help address issues in the Interim Measures report (Wilhite and Butcher, 2003) will incorporate the 331-M standards' waste. The planned Special Analysis may provide intruder limits that include leaching and a separate set of limits that exclude leaching. In that case the 331-M standards' waste would be covered by the limits that exclude leaching.

\section{$\underline{\text { References }}$}

1. Collard, L.B., 2003A. Evaluation of Proposed New LLW Disposal Activity: Disposal of Beneficial Reuse Containers Manufactured from Activated Metals, WSRC-TR-2003-00058, Rev. 0. Savannah River Laboratory, Westinghouse Savannah River Company, Aiken, SC., January 27, 2003.

2. Collard, L.B., 2003B. Special Analysis: Implementation of Sum-of-Fractions for Multiple Pathways Including Select Groundwater Pathway Time Intervals, WSRC-TR2003-00438, Rev. 0. Savannah River Laboratory, Westinghouse Savannah River Company, Aiken, SC., September 15, 2003.

3. Cook, J.R., E.L. Wilhite, and L.B. Collard, 1999. Addendum to the Composite Analysis for the E-Area Vaults and Saltstone Disposal Facilities. WSRC-RP-99-00844, Rev. 0. Savannah River Laboratory, Westinghouse Savannah River Company, Aiken, SC., September 23, 1999. 
4. DOE, 1999. Disposal Authorization Statement for the Department of Energy Savannah River Site E-Area Vaults and Saltstone Disposal Facilities, September 18, 1999.

5. Gregory, C.A., 2003. 331-M Standards, Calculation Note G-CLC-M-00018, Westinghouse Savannah River Company, Aiken, SC., April 23, 2003.

6. McDowell-Boyer, L., A.D. Yu, J.R. Cook, D.C. Kocher, E.L. Wilhite, H. HolmesBurnes, and K. E. Young, 2000. Radiological Performance Assessment for the EArea Vaults Disposal Facility. WSRC-RP-94-218, Rev. 1. Savannah River Laboratory, Westinghouse Savannah River Company, Aiken, SC., January 31, 2000.

7. Reed, S.R., 2003. Unreviewed Safety Question Screening, E-Area Slit Trench Disposal of One B-25 Containing 313-M U-235 Standards, USQ-SWE-2003-0034, September 11, 2003 (attached).

8. Wilhite, E.L. and B.T. Butcher, 2003. E-Area Performance Assessment Interim Measures Assessment FY2003. WSRC-RP-2003-00436, Rev. 0. Savannah River Laboratory, Westinghouse Savannah River Company, Aiken, SC., July 15, 2003. 


\section{Attachment - USQ Screening}

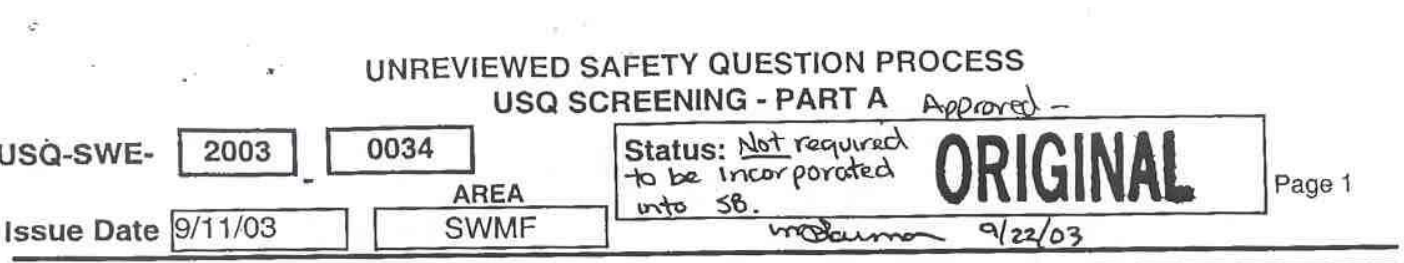

Title: E-Area Slit Trench Disposal of One B-25 Containing 313-M U-235 Standards

Description of Proposed Activity* (or Discovery):

Facilities Disposition Projects plans to ship a B-25 box from 331-M containing U-235 standards for E-Area Slit Trench disposal. The proposed activity (PA) involves the receipt, handling, storage and disposal of this B-25 containing U-235 standards which has a U-235 fissile gram equivalent (FGE) inventory of 1064 grams (or less). The current U-235 FGE analysis B-25 container limit is 423 grams (ref. 4) with an administrative B-25 container limit of 370 grams (ref. 5), assuming no stacking of the B-25 with Sealand Containers.

The PA also adopts a Nuclear Criticality Safety Assessment (NCSA) WSRC-TR-2003-00356, Nuclear Criticality Safety Assessment. Receipt, Handling and Storage of Single 331-M Standards Bearing B-25 (ref. 6) that was completed to consider E-Area Slit Trench disposal of this specific B-25.

Table 6.4-1 of Chapter 6 of Reference 2 is hereby amended to add a one-time B-25 container limit of 1064 FGE U-235 or less per Reference 6 . It should be noted that although the established B-25 adminstrative limit is being increased for this one 331-M B-25 container, the Slit Trench Segment FGE inventory limits as specified in Reference 5 will remain the same (7500 FGE U-235 analysis limit and 6000 FGE U-235 administrative limit). Container stacking limits as specified in Section 7.0 of Reference 5 will also remain the same.

Types of waste to be disposed in the subject facilities and waste handling and disposal techniques are not changed by the PA. The facilities remain Hazard Category 3 . WITS will continue to be used to limit the inventory in the facilities and containers placed in the facilities.

-Include intermediate configurations which might result from the proposed activity. 


\begin{tabular}{l} 
UNREVIEWED SAFETY QUESTION PROCESS \\
USQ SCREENING - PART A \\
USQ-SWE- 2003,0034 \\
ISSue Date $9 / 11 / 03$ \\
\hline SWMF
\end{tabular}

\section{SCREENING ORIGINATOR}

1 Does the Proposed Activity involve a change to the TSRs/OSRs?

Provide Justification for YES or NO answers.

The proposed activity does not impact the TSRs (ref. 1). The following TSR controls relate to the E-Area Slit Trenches:

TSR 5.5.2.5 - The TSR is that waste be accepted under an approved Waste Acceptance Criteria.

DISCUSSION: This waste item (B-25 box containing standards) will be accepted under and approved WAC Deviation for elevated FGE.

TSR 5.5.2.6.1.a - The TSR requires that a means of inventory control is established.

DISCUSSION: As with all waste receipts, WITS and the approved WAC Deviation will provide adequate inventory control.

TSR 5.5.2.6.15. The TSR requires that the entire E-Area Slit Trench facility is maintained as a single Hazard Category 3 (HC-3) facility.

DISCUSSION: Receipt of this waste item will not put the facility outside of the HC-3 limits sum of fraction or impact facility segmentation. Additionally, Reference 6 demonstrates that an inadvertent criticality resulting from the PA is incredible.

TSR 5 5.2.7.7.b - This TSR requires that Hazard Category 3 facilities have inventory controls imposed to insure that inventory limits specified in Chapter 6 of the SWMF SAR are maintained.

DISCUSSION: This USQ adopts an additional Chapter 6 limit for Slit Trench disposal of one specific B-25 waste container thus insuring continued compliance with this TSR as written.

II YES, prior DOE approval through the TSFUOSF change process is required, no further USO screening or evaluation is required, GO TO Block 3 and 4 and complete. II NO, continue with screening. 


\section{UNREVIEWED SAFETY QUESTION PROCESS}

USQ SCREENING - PART A

\begin{tabular}{l} 
USQ-SWE- $2003 / 20034$ \\
Issue Date $9 / 11 / 03$ \\
\hline SWE
\end{tabular}

2 Does the Proposed Activity involve:

A. A change to the facility as described in the Documented Safety Analysis?

$\square$ NO $\triangle$ YES

B. A change to procedures as described in the Documented Safety Analysis?

QNO $\square$ YES

C. A test or experiment not described in the Documented Safety Analysis?

区NO $\square$ YES

D. Analytical errors, omissions or deficiencies in the Documented Safety Analysis?

囚NO $\square$ YES

NOTE: Justification is required when all section 2 questions $(2 A, 2 B, 2 C$ and $2 D)$ are answered NO.

A. Disposal of a single B-25 box containing 1064 grams of fissile gram equivalent U-235 exceeds the current B-25 box package limit as described in the recent Slit Trench limit USQ Evaluation (ref. 5). Therefore, a USQ Evaluation is required.

B. There are no procedures in the SAR that relate to E-Area Slit Trench disposal.

C. The PA is not a test or an experiment.

D. The PA does not involve analytical errors, omissions or deficiencies. 
UNREVIEWED SAFETY QUESTION PROCESS USQ SCREENING - PART A

\begin{tabular}{l} 
USQ-SWE- $2003 / 0034$ \\
Issue Date $9 / 11 / 03$ \\
\hline SWMF
\end{tabular}

LIST REFERENCES DOCUMENTS USED IN COMPLETION OF THE USQ SCREENING. ALSO FOR USQ EVAULATIONS LIST REFERENCES DOCUMENTS AS REQUIRED.

1. WSRC-TS-95-16, Technical Safety Requirements - Savannah River Site - Solid Waste Management Facility, Rev, 4, May 2003.

2. WSRC-SA-22, Safety Analysis Report - Savannah River Site - Solid Waste Management Facility, Rev. 4, May 2003.

3. WSRC-RP-94-218, Rev. 1, Radiological Performance Assessment For The E-Area Low-Level Waste Facility, January 2000.

4. N-NCS-E-00022, Nuclear Criticality Safety Evaluation: Disposal Limits for E-Area Slit Trenches, Rev. 0, June 24, 2003

5. USQ-SWE-2003-0019, Adoption of Nuclear Criticality Safety Evaluations N-NCS-E-00020 (Component-in-Grout Trench) and N-NCS-E-00022 (Slit Trench), Rev. 0, June 9, 2003.

6. WSRC-TR-2003-00356, "Nuclear Criticality Safety Assessment. Receipt, Handling and Storage of Single 331-M Standards Bearing B-25 (U)," WSMS, Aiken,SC, August 14, 2003. 
